\title{
THE CHROMOSOMES OF CHRYSANTHEMUM, II: GARDEN VARIETIES
}

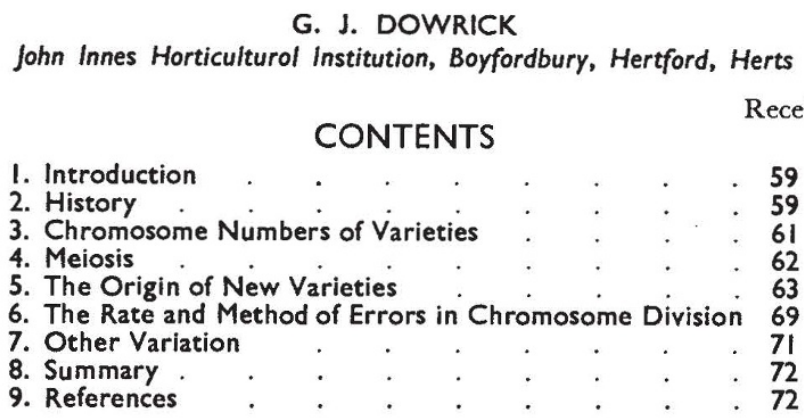

\section{INTRODUCTION}

NEw varieties of the garden chrysanthemum arise primarily from seed. They are propagated vegetatively and many give rise to bud sports in sequence and in parallel to give whole families of varieties. The original sports would naturally be chimæras and it is not surprising therefore that they often revert to the previous type. Whereas some varieties sport continually from the time of their origin, others remain stable for many years. Those considered in this account do, mostly, sport freely. Since varieties may remain stable for a considerable number of years and then suddenly sport it is probable that all varieties possess the ability to sport. The origin of bud sports is unpredictable.

Some confusion in naming has arisen as the same or similar sports have occurred and been propagated in different places under different names. Consequently there are, for example, several forms similar to, but not identical with, the original Favourite Supreme raised by Messrs A. G. Vinten. It might well be that each individual variety would be better termed a sub-family to include all its minor variants. The different Chrysanthemum sports are described in scattered numbers of the R.H.S. Fournal-more particularly, for the Favourite family, in Vol. 63, r 938, pp. 139-141.

The object of this study is to discover the cause of sporting.

\section{HISTORY}

The first written reports of the cultivated Chrysanthemum date from about 500 B.c. but it had undoubtedly been grown for decoration previously. The original garden Chrysanthemum was probably a single, many-flowered variety similar to $C$. indicum which still occurs naturally in China and Japan. Cultivation has resulted in transformation of the corolla of individual florets in one of three directions. The small 
five-toothed disc florets give rise either to broad flat ray florets or, alternatively, elongation without splitting results in quilled or tasselled forms. Increase in size of the disc florets produces anemone-centred types.

These changes have been accompanied by atrophy of the male sex organs. There is reduction in anther size and, in some cases, only the stalks remain, while in others all traces have disappeared. In A.D. $3^{86}$ the Chrysanthemum reached Japan, via Korea, from China where it was first cultivated. Here it was selected and improved to give a great variation in form and colour. Most present-day forms of the flower were evolved in Japan over 1000 years ago.

In I 754 a small-flowered type was introduced into England from Holland where it had been cultivated as Matricaria Faponica. This plant was subsequently lost. In I 790 a large-flowered variety, "Old Purple", was introduced (Curtis, I 796). Its inflorescence and general habit were similar to many present-day varieties and it was then considered a form of $C$. indicum. After 1820 more varieties were introduced from China and by 1826 forty-eight were known. In 1827 new forms were first produced by hybridisation and from these have arisen the incurved types of to-day. The first vegetative sport was noticed in $183^{2}$.

In I843 Robert Fortune sent to England the first Pompon-the Chusan Daisy - from which numerous modern forms have been raised. He returned in $186 \mathrm{I}$ with seven Japanese varieties, the forerunners of the so-called Exhibition 7apanese types. The first early flowering varieties were selected from existing stocks in about 1850 .

Since then there have been other introductions such as the Korean and Midget types. In $1930 \mathrm{McGregor}$ sent from China a plant, similar to $C$. indicum, from the progeny of which were selected Sutton's Charm and Cascade.

The ancestry of many of these garden chrysanthemums is unknown. The similarity of chromosome size and form both between and within species removes one source of guidance. Cultivation and selection for so long may have resulted in plants bearing little resemblance to their ancestral species.

C. indicum, with its yellow flowers, is undoubtedly involved in the ancestry but whether it is the only species involved is uncertain. Hemsley (1889) considers $C$. sinense (morifolium) to be another likely parent. It is more robust than $C$. indicum, has tomentose leaves and ray florets differing in colour from the disc. Stapf (1933) considers the following species may also be involved : C. erubescens, a very distinct species with somewhat succulent like leaves and pink-rayed flower heads, together with C. ornatum, C. japonense and C. makinoi. $\mathrm{He}$ considers it improbable that oriental gardeners would ignore these naturally occurring species and concentrate on one only. He supposes that the garden Chrysanthemum has resulted from hybridisation and selection of them all. 
All these species are hexaploid $(2 n=6 x=54)$ excepting $C$. makino $i$ which is diploid $(2 n=18)$. This latter can now be disregarded since the garden forms were, it seems, themselves originally hexaploid.

Other cultivated species of Chrysanthemum have been considered in the previous study.

\section{CHROMOSOME NUMBERS OF VARIETIES}

The somatic chromosome numbers of $6_{5}$ varieties * vary between $2 n=47-63$, this including both $6 x$ and $7 x$ types $(x=9)$. Most
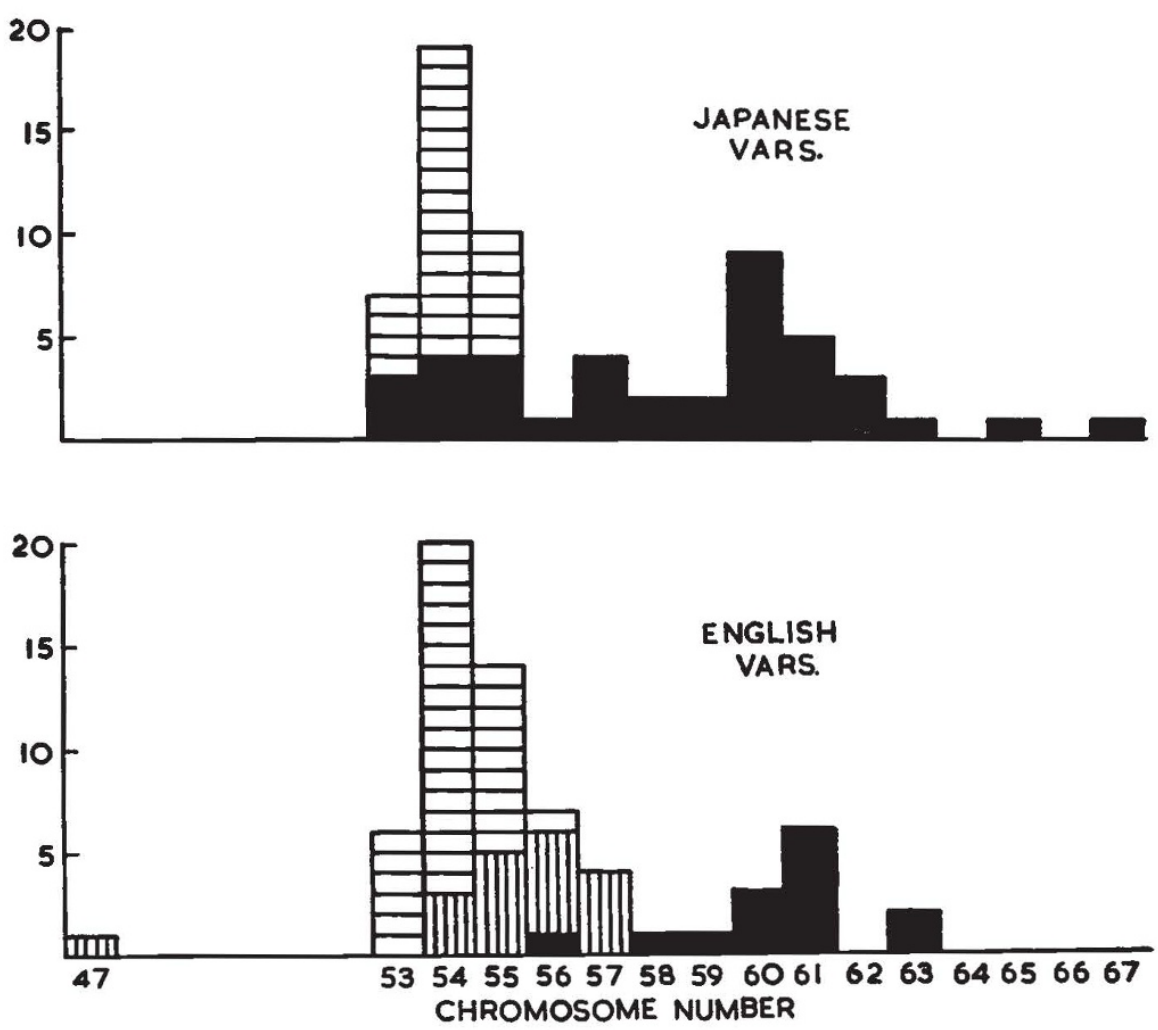

Fig. 1.-Chromosome numbers of varieties considered in the present account are shown in the lower graph. The upper graph is compiled from the results of Shimotomai (1933). Varieties are divided into three groups of increasing inflorescence size. Those shaded horizontally are less than $12 \mathrm{~cm}$. in diameter, those vertically between 12 and $20 \mathrm{~cm}$. and those in black over $20 \mathrm{~cm}$. The large varieties of Shimotomai correspond to the medium and large English varieties.

varieties have between $54-56$ chromosomes with the peak at $2 n=54$. Varieties have been separated into three groups of increasing inflorescence diameter. This increase in size is accompanied by increase in chromosome number (fig. I).

* Root-tip squashes with the Feulgen technique were used, roots being pre-treated with mono-bromo-naphthalene for three hours (O'Mara, 1948). Acetic alcohol was the fixative and the hydrolysis time $15 \mathrm{mins}$. at $60^{\circ} \mathrm{C}$. This method, though facilitating easy and rapid counting, has a disadvantage in that some cells become broken with inevitable loss of one or more chromosomes. Such cells are not considered. 
Shimotomai (I933) carried out the only previous investigation of Chrysanthemum varieties. He divides them into two size groups only, one similar to the small English varieties, the other including those of medium and large size. In both English and Japanese varieties 54 is the most frequent number and in each the small-flowered forms have, mainly, between 53-55 chromosomes.

The range in chromosome number for medium and large varieties of the two areas together is $54-67$. Medium-sized English varieties, with one exception, have 54 to 57 . Large varieties have 56 to 63 . Size groups and chromosome numbers correspond remarkably in the varieties from the two areas.

\section{MEIOSIS}

Meiosis in the varieties is regular. Those with 54 chromosomes invariably have 27 bivalents at MI and form pollen with 27 chromo-
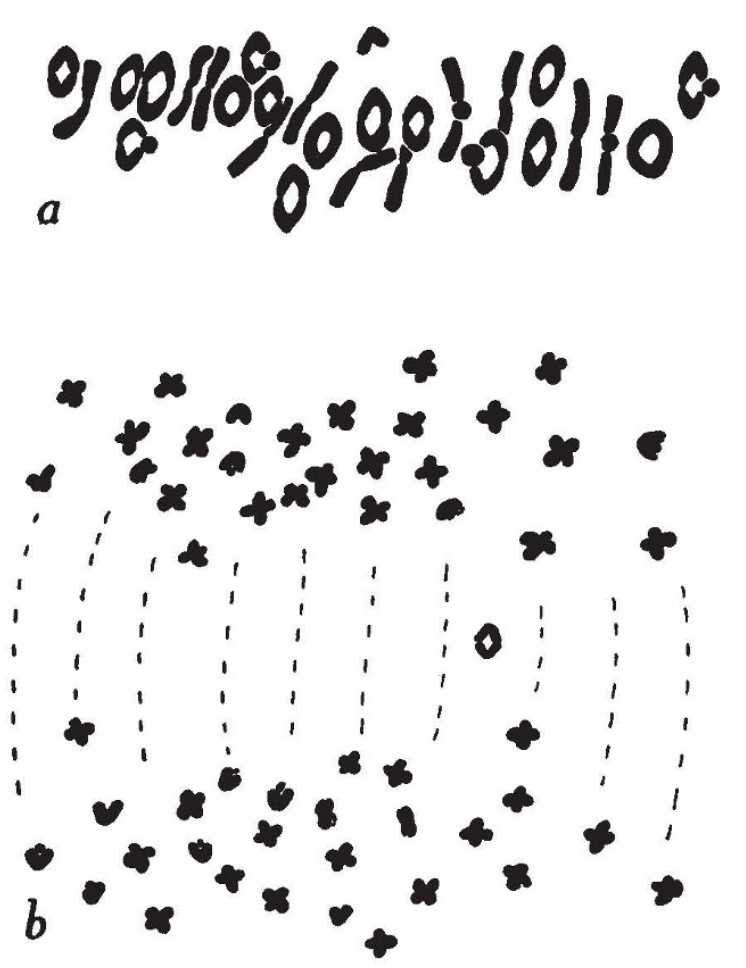

FIG. 2.-(a) First metaphase and (b) First anaphase in Market Gold $2 n=55 . \quad \times 1800$.

somes. Unbalanced forms usually have one or more univalent. Thus MI in varieties with 53 chromosomes have 26 pairs and one univalent, while forms with 55 have 27 pairs and one univalent (Fig. 2). The extra chromosome has not been seen to form a trivalent with a normal bivalent. Quadrivalents occurred in two cells; these may be due 
either to associations of four homologous chromosomes or to interchanges.

Univalents, when present, normally divide at AI and may or may not be contained in the pollen. The pollen then has either 27 or 28 chromosomes. There is throughout a minimum of irregularity and the ripe pollen grains have uniform chromosome numbers.

\section{THE ORIGIN OF NEW VARIETIES}

Accompanying chromosome variation between varieties there is also variation within individual plants. Two or more chromosome numbers have been found within a single root (table I). For example, of twelve cells counted in the variety $W e n d y$, ten had 54 , one had 53 and one $5 \mathrm{I}$ chromosomes. This type of variation is found in 20 of 65 varieties examined. While in its simplest form it involves only the gain or loss of a single chromosome, more complex changes involving a number of chromosomes are found (Fig 5). Different types of variation found are shown in fig. 3 .

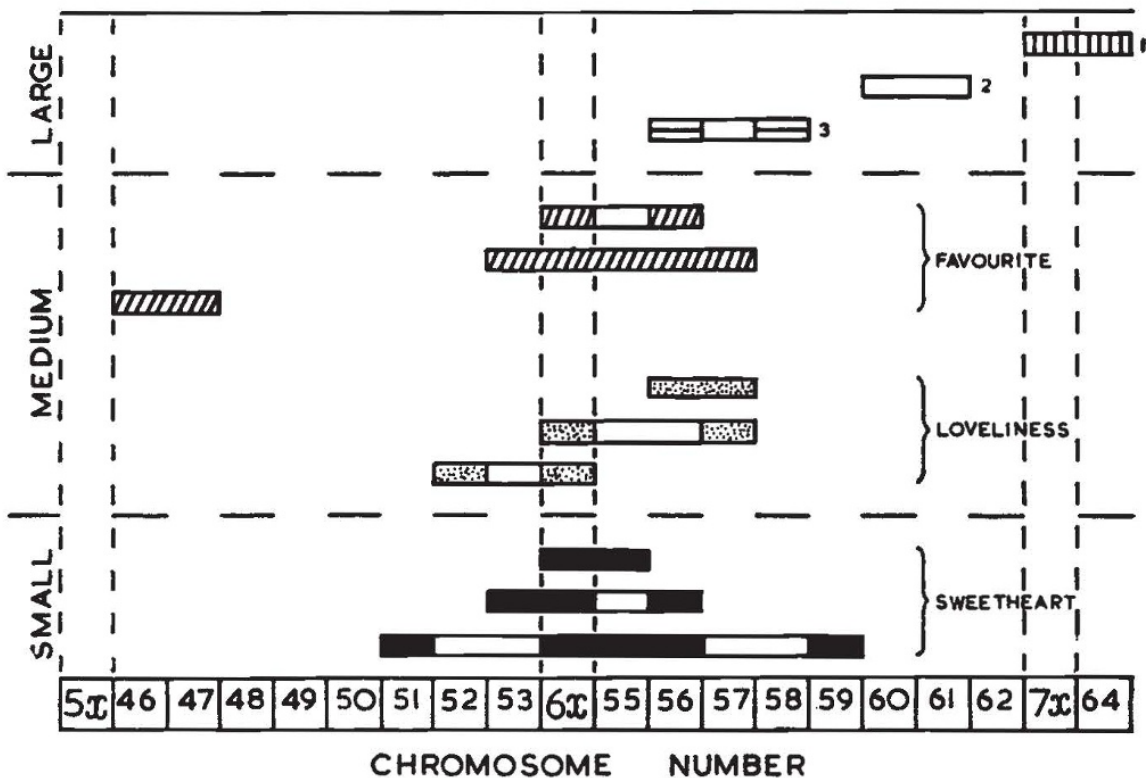

FIG. 3.-Variation within individuals of three families with small and medium-sized inflorescences is shown together with that in (1) Birmingham; (2) rellow Majestic, and Florence Reed and (3) Mrs R. C. Pulling-these latter all being large varieties.

The questions then arise whether there is any connection between this type of variation and the origin of somatic sports, and whether there are differences between chromosome complements of the sports of a family that account for changes in flower colour. To settle these points, seven different sports from The Favourite were obtained. The vegetative ancestry of each was known. The original Favourite, a white-flowered plant, has given rise to three sports Pink, Golden, and 
Favourite Supreme (the last pinkish bronze). Another five have arisen from these either directly or indirectly (fig. 4).

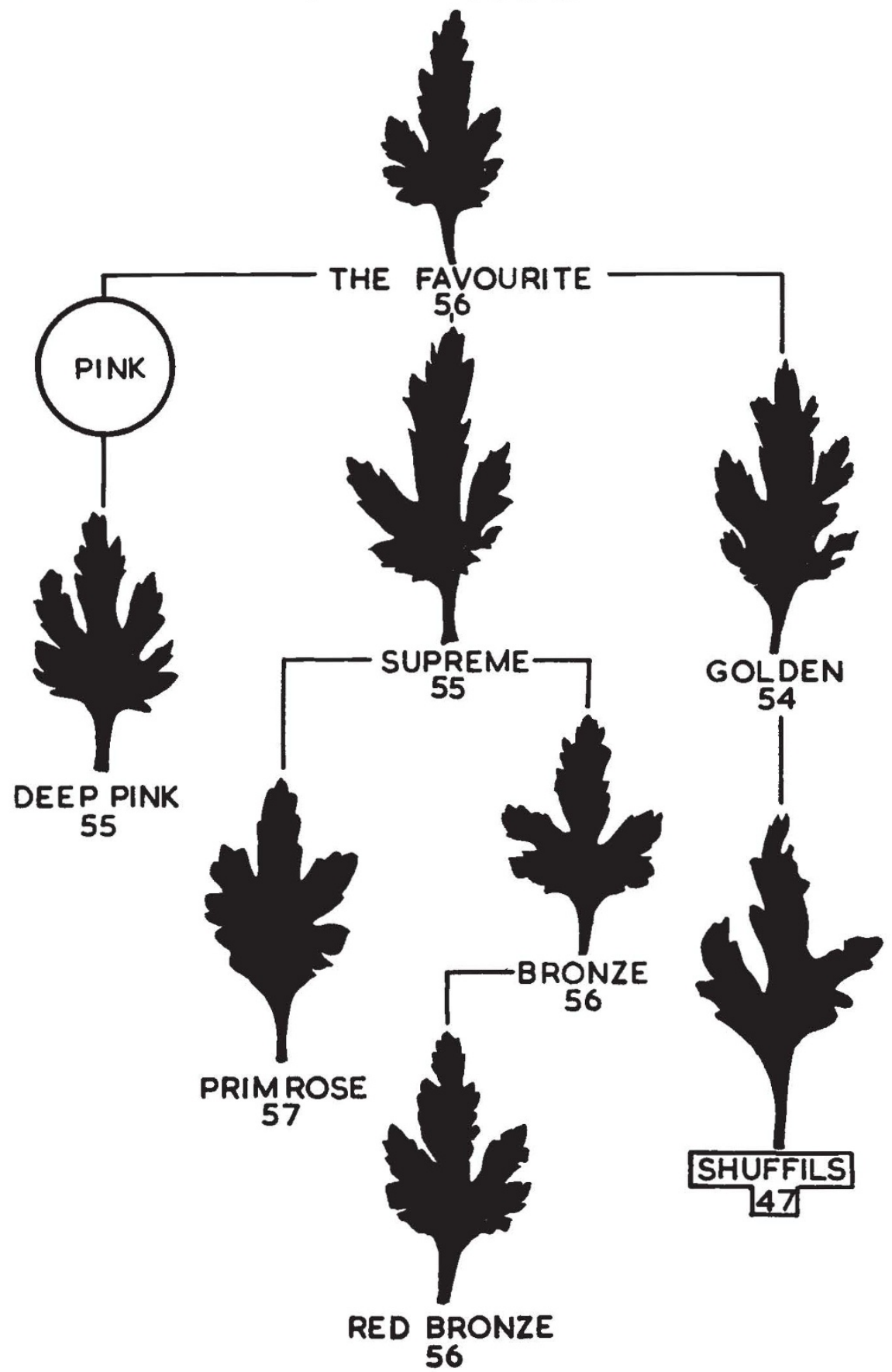

Frg. 4.-The genealogy of the bud sports family of Favourites with the chromosome number and leaf shape characteristic of each. Note Shuffil's Favourite with low chromosome number and aberrant leaf shape. 
In The Favourite 20 cells had 56 and two had 54 chromosomes. Two of its three sports were examined and had 55 and 54 chromosomes. In one sport, Golden Favourite $2 n=54$, while cells with 53, 54, 55, 56 and 57 were found (table I). From this plant arose Shuffil's Favourite $(2 n=47)$ with reddish flowers. The loss of 7 chromosomes is accompanied by weakness and deformity. It also shows variation, having cells with 46 chromosomes.

A similar survey was carried out with two other families of sports from the Sweetheart and Loveliness parents (table r). Results in these are similar to those in the Favourites, although in both the total range of chromosome numbers is smaller.

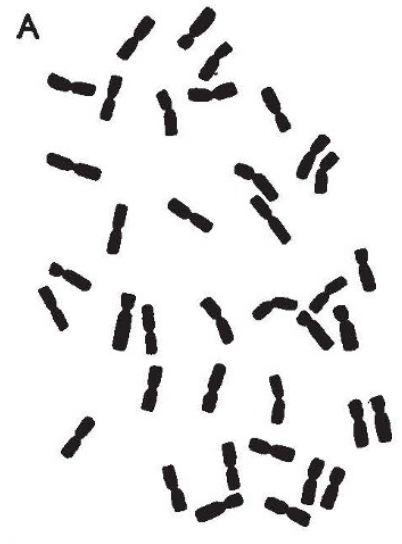

1

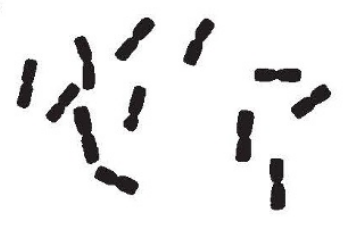

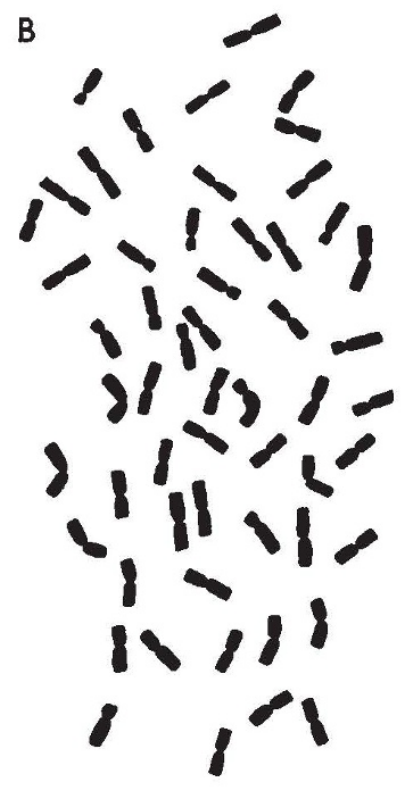

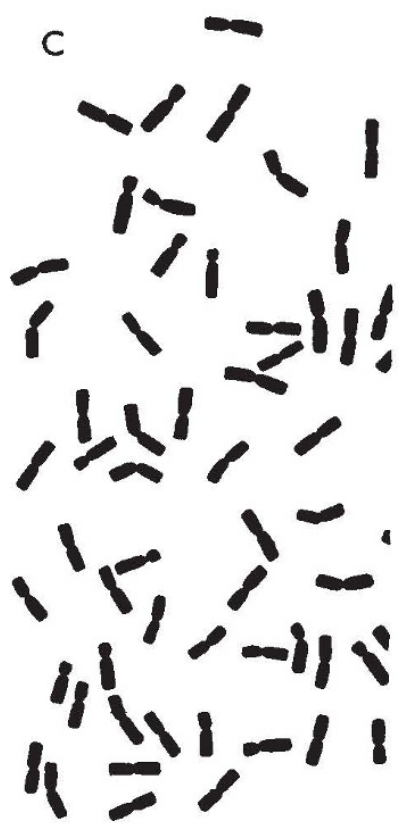

Fig. 5.- Orange Sweetheart. Three cells from a single root-tip $(a) 2 n=5 \mathrm{I}$;

(b) $2 n=55$ and $(c) 2 n=59 . \times 1800$.

Vegetative sports within these families thus arise from somatic variation in chromosome number. Sporting, together with chromosome variation brought about by sexual reproduction, will account for the range in chromosome number found throughout the varieties.

Although variation in chromosome number occurs from $6 x$ to $7 x$ there is no similar decrease towards $5^{x}$. Chromosome loss would, normally, have a much greater effect than gain, and with it abnormalities would increase. Thus Shuffl's Favourite and similar plants would be less liable to survive. The absence of the $5^{x}$ group is therefore to be expected.

There is throughout Chrysanthemum uniformity in form and size between the chromosomes of the basic complement (Dowrick, I952). In hexaploid varieties it is impossible to say whether all nine chromo- 
somes are present six times, or some seven times or more with others five or less. This is important when considering different colour sports of identical chromosome number. In, for example, both

TABLE I

The frequency of different chromosome numbers within varieties of Chrysanthemum.

$\mathrm{L}$, large ; $\mathrm{M}$, medium; S, small flowered

\begin{tabular}{|c|c|c|c|c|c|c|c|c|c|c|c|c|c|c|}
\hline \multirow{2}{*}{ Variety } & \multirow{2}{*}{$\begin{array}{c}\text { Nos. } \\
\text { of } \\
\text { roots }\end{array}$} & \multicolumn{13}{|c|}{$\begin{array}{l}\text { Nos. of mitotic cells with different } \\
\text { chromosome numbers }\end{array}$} \\
\hline & & 46 & 47 & $5^{I}$ & 52 & 53 & 54 & 5 & 56 & 57 & $5^{8}$ & 59 & 60 & 61 \\
\hline $\begin{array}{l}\text { SwEETHEART } \\
\text { Apricot } \\
\text { Egerton } \\
\text { Golden } \\
\text { Peach } \\
\text { Pearl : } \\
\text { Red : } \\
\text { Bronze } \\
\text { Sweetheart } \\
\text { Salmon } \\
\text { Orange }\end{array}$ & $\begin{array}{l}2 \\
2 \\
2 \\
2 \\
3 \\
3 \\
2 \\
3 \\
2 \\
2\end{array}$ & & & I & - & $\begin{array}{l}\overline{-} \\
\overline{-} \\
\overline{-} \\
\overline{-} \\
\bar{I}\end{array}$ & $\begin{array}{l}= \\
= \\
Z \\
7 \\
3 \\
10\end{array}$ & $\begin{array}{l}x \\
x \\
x \\
x\end{array}$ & $\begin{array}{l}\bar{z} \\
10 \\
= \\
= \\
= \\
\overline{2} \\
6\end{array}$ & - & - & I & & \\
\hline $\begin{array}{l}\text { Favourrte F } \\
\text { Bronze } \\
\text { Fav. Supreme } \\
\text { Deep Pink } \\
\text { Primrose } \\
\text { Red Bronze } \\
\text { White. } \\
\text { Shuffil's } \\
\text { Golden } \\
\text { Lovelingss F } \\
\text { Amber } \\
\text { Apricot } \\
\text { Loveliness } \\
\text { Primrose } \\
\text { Purple } \\
\text { Salmon } \\
\text { Salmon Bron } \\
\text { White. } \\
\text { Bronze } \\
\text { Lilac. }\end{array}$ & $\begin{array}{l}2 \\
2 \\
2 \\
2 \\
2 \\
4 \\
3 \\
2 \\
3 \\
3\end{array}$ & 2 & 10 & - & - & - & $\begin{array}{l}I \\
I \\
I \\
I\end{array}$ & $\begin{array}{l}= \\
= \\
= \\
=\end{array}$ & $\begin{array}{r}7 \\
10 \\
11 \\
11 \\
9 \\
13 \\
8 \\
10 \\
- \\
-\end{array}$ & 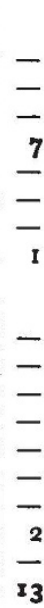 & & & & \\
\hline $\begin{array}{l}\text { Majestic FaM } \\
\text { Red Majestic } \\
\text { rellow Maje } \\
\text { Florence Reed }\end{array}$ & $\begin{array}{l}3 \\
3 \\
3\end{array}$ & & & & & & & - & $\bar{z}$ & $\frac{8}{-}$ & $\bar{z}$ & $\bar{z}$ & $\begin{array}{l}- \\
1 \\
8\end{array}$ & $\begin{array}{r}- \\
10 \\
1\end{array}$ \\
\hline
\end{tabular}

Egerton and Red Sweetheart the diploid number is 55 (fig. 6). But the flower colours are quite distinct. Presumably the same 55 chromosomes are not involved.

The present counts were made from roots. Young roots originate endogenously and arise from few cell layers. They do not necessarily give a picture of all the different numbers found in other parts of the 
plant. The origin of new stems is more complex. Lateral branches are multicellular in origin, arising from many layers. Popham and Chan (1950) distinguish five zones in the shoot apex of the cultivated Chrysanthemum, differing both in the plane and frequency of their

TABLE I (continued)

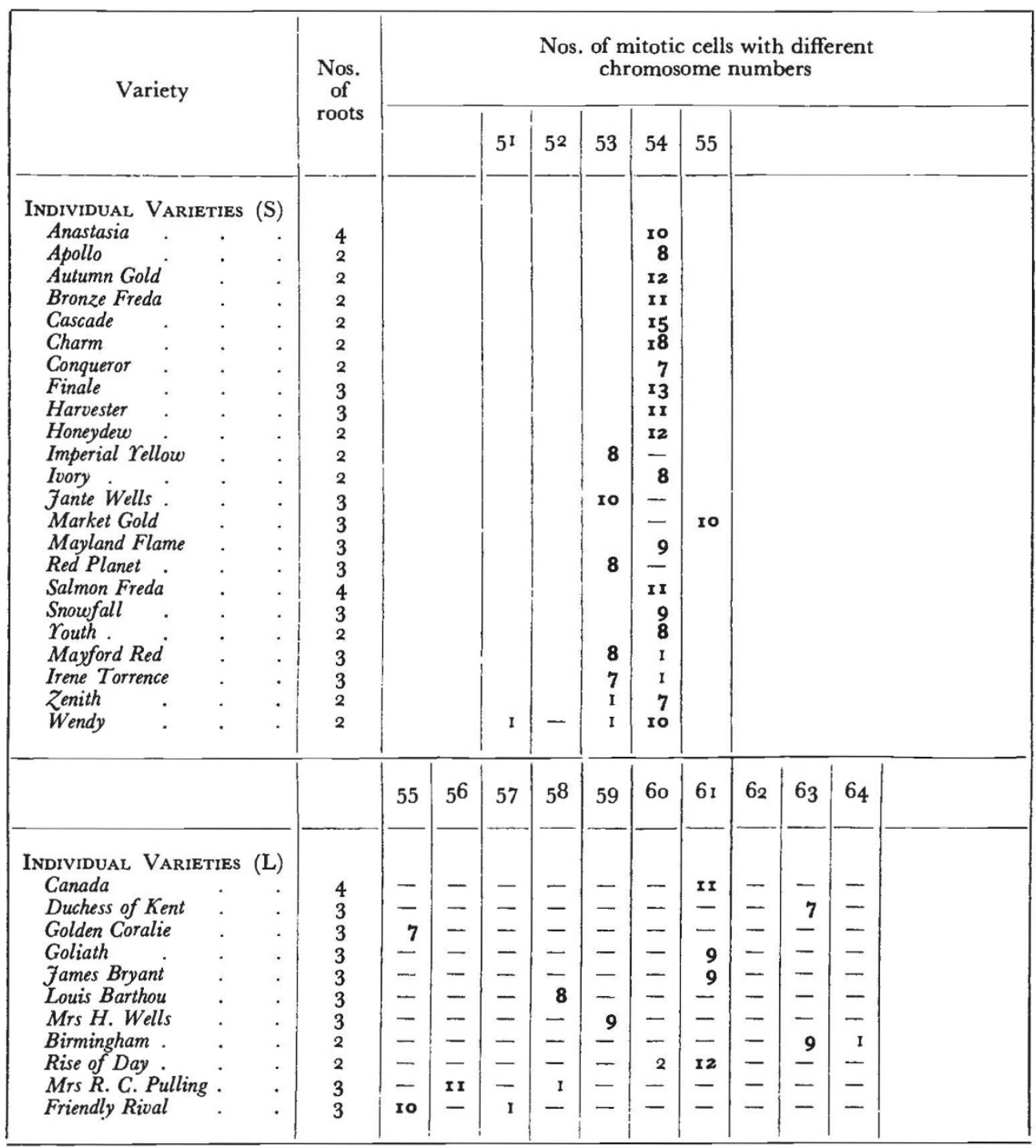

divisions. The outer tunica of two to five cell layers mainly undergoes anticlinal divisions; the outermost layer never divides periclinically, while the inner zones undergo divisions in all planes. The rate of division is, however, greater towards the centre of the shoot. The number of daughter cells perpetuating an error in division will, therefore, decrease the nearer the error is to the epidermis. But 
wherever it occurs it results in a chimæra which at first is mericlinal and later periclinal, in its own lateral branches. The cell layers towards the centre of the stem are not contained in the petals, and changes in their chromosome numbers will probably not affect flower colour. Similarly anthocyanin is found only in the epidermis ; changes in that layer alone will affect the type or amount of anthocyanin produced.

Preliminary work on flower pigments of Chrysanthemum suggests that colour differences between different sports of a family are due
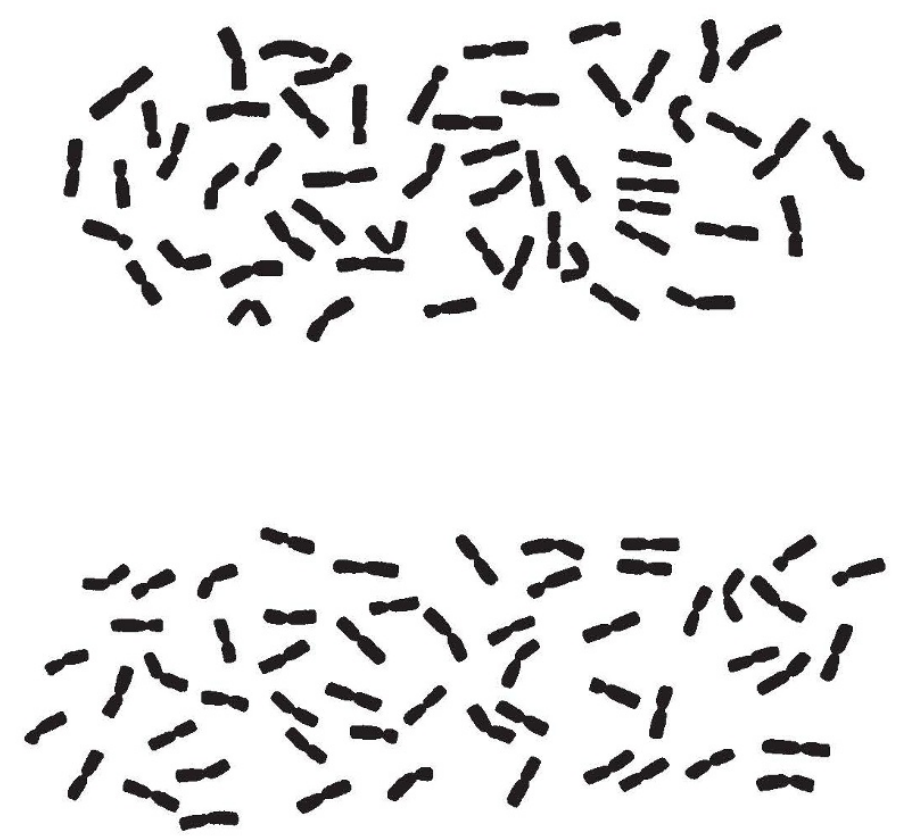

Fig. 6.-Cells of Egerton and Red Sweetheart. In both $2 n=55 . \quad \times 1800$.

to quantitative differences between the pigments present (Dayton, unpub.). Qualitative differences could also occur without change in the type of genetic material present (Scott-Moncrieff, 1936).

It must be assumed that the different sports are, at first at least, chimæras. This characteristic will be retained by vegetative propagation. The continual throwing of some sports from particular varieties is thus to be expected, as for example, Lizzie Adcock, which continually arises from Florrie Ford.

Another case has been reported to me recently by $\mathrm{Mr} \mathrm{L}$. G. Atkins the Horticultural Advisory Officer of Lincolnshire. In a letter he says that a grower found that hot-water treatment at $40^{\circ} \mathrm{C}$. for 20 mins. to protect the variety Bronze Favourite against eelworm resulted in the production of 20 per cent. of plants similar to, and which might be assigned to the same sub-family as, Pink Favourite. 
It is probable that this treatment leads to the replacement of one layer by another at the growing tip. The original Pink Favourite arose directly from White Favourite and so here we have a method whereby the same, or similar, sports can arise in two quite distinct ways. Such parallel sports need not have the same chromosome number.

\section{THE RATE AND METHOD OF ERRORS IN CHROMOSOME DIVISION}

The question then arises how these variations come about. Observations have been made on mitotic anaphases and telophases in longitudinal sections of both root and stem tips. The rate and method of abnormality in stem tips only is considered here, as results are similar in both. Doubtful divisions were not scored.

\section{TABLE 2}

The rate of abnormal chromosome division found in different varieties of three families under constant temperature conditions $\left(I I \cdot 6^{\circ} \mathrm{C}\right.$.)

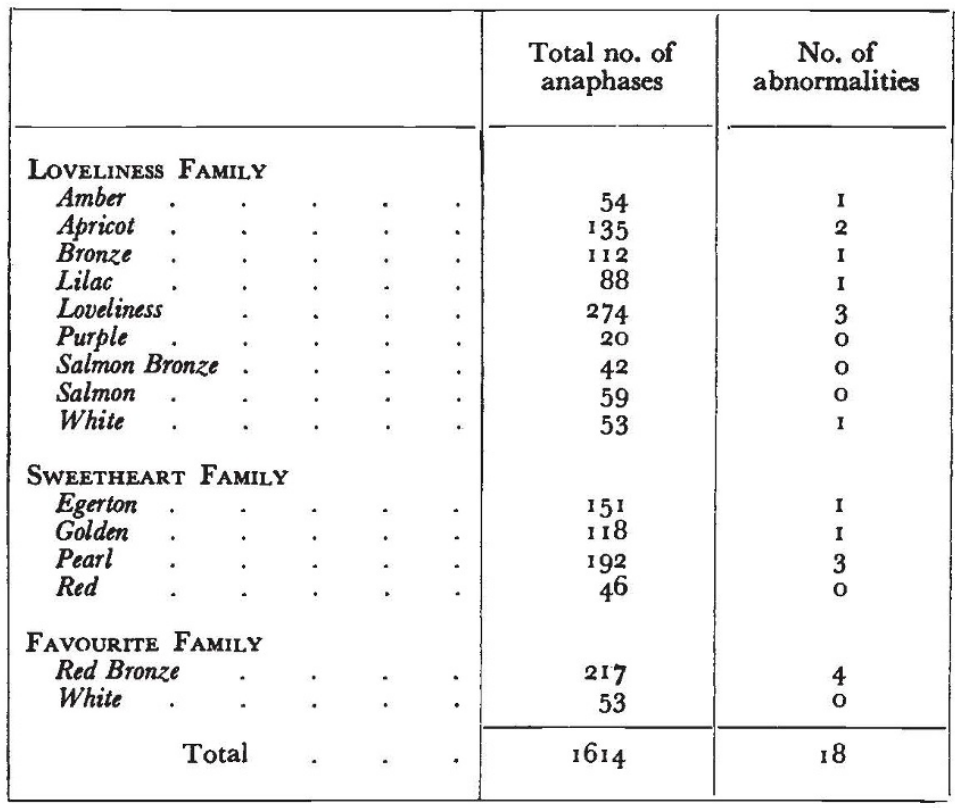

Plants used in these tests were kept at a constant temperature of I I $6^{\circ} \mathrm{C}$., both before and during the experiment. There were I 8 abnormal divisions in ${ }^{1} 6 I_{4}$ analysed; a frequency of $I \cdot I$ I per cent.

It was then necessary to see whether environmental conditions influence the number of abnormal mitoses. Plants were placed in a constant temperature room at $23.5^{\circ} \mathrm{C}$. for 3 days and then transferred to a refrigerator at $3.5^{\circ} \mathrm{C}$. Root and stem tips were examined 
24 and 48 hours after the temperature shock. A similar experiment with reciprocal temperature change was carried out simultaneously.

The first experiments had insufficient divisions for analysis. In the second there were 84 divisions after 24 hours, two of which showed errors. The results after $4^{8}$ hours are summarised in table 3. Here

TABLE 3

The rate of chromosome abnormality at anaphase at a constant temperature of ${ }_{I I} \cdot 6^{\circ} \mathrm{C}$. and following a temperature shock intercalated between temperatures of $3.5^{\circ} \mathrm{C}$. and $23.5^{\circ} \mathrm{C}$.

\begin{tabular}{|c|c|c|c|c|c|c|c|c|}
\hline \multirow{2}{*}{\multicolumn{2}{|c|}{ Variety }} & & \multicolumn{3}{|c|}{ Constant temperature I I $6^{\circ} \mathrm{C}$. } & \multicolumn{3}{|c|}{ Temperature shock } \\
\hline & & & $\begin{array}{c}\text { Total no. } \\
\text { cells }\end{array}$ & $\begin{array}{c}\text { No. of } \\
\text { abnormal }\end{array}$ & $\begin{array}{l}\text { Per cent. } \\
\text { abnormal }\end{array}$ & $\begin{array}{c}\text { Total no. } \\
\text { cells }\end{array}$ & $\begin{array}{c}\text { No. of } \\
\text { abnormal }\end{array}$ & $\begin{array}{l}\text { Per cent. } \\
\text { abnormal }\end{array}$ \\
\hline \multicolumn{9}{|c|}{ LOVELINESS FAMILY } \\
\hline Amber & & . & 54 & I & $1 \cdot 85$ & 55 & I & $1 \cdot 82$ \\
\hline Bronze . & & . & 112 & I & 0.89 & $12 \mathrm{I}$ & 2 & $r \cdot 57$ \\
\hline Loveliness. & & . & 274 & 3 & $r \cdot 09$ & 71 & I & $I \cdot 3$ \\
\hline Purple . & . & . & 20 & $\ldots$ & $\ldots$ & 86 & 2 & $2 \cdot 3$ \\
\hline Salnon Bronze & • & . & $4^{2}$ & $\cdots$ & $\cdots$ & 63 & $\cdots$ & $\cdots$ \\
\hline Total & . & . & 502 & 5 & 0.99 & 396 & 6 & $I \cdot 5 I$ \\
\hline
\end{tabular}

the frequency of error is 1.5 per cent.; higher than under normal conditions.

It is to be expected, therefore, that chromosome variation in roots will depend partly on those external factors which influence the rate of abnormality. It must also be assumed that the variation within individuals, as shown in table $\mathrm{r}$, will not necessarily be complete.

TABLE 4

The frequency of different types of abnormal cell divisions in treated and untreated plants

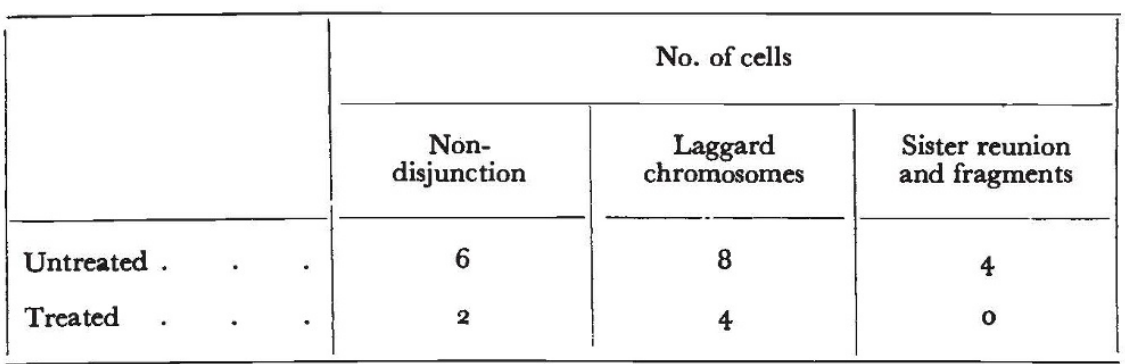

The types of anaphase abnormalities observed are shown in fig. 7 and plate 1 . The most common result from non-disjunction of a single pair of chromosomes so that each daughter nucleus gains or loses one chromosome. Alternatively one or both of a pair of daughter chromosomes may lag in separation and are lost. 


\section{Plate}

Chromosome numbers in root-tip cells

1. Orange Sweetheart $2 n=55 . \quad \times 1400$.

3. Orange Sweethent $2 n=5 \mathrm{I} . \quad \times 1400$.

2. Orange Sweetheart $2 n=50 . \quad \times 1400$.

Types of error in chromosome division in Salmon Sweetheart

4. Incomplete separation of daughter chromomomes at anaphase. $\times 1400$.

5. Nondisjunction of a pair of chromosomes. $\times$ iooo.

6. Single laggard chromosome at telophase. $\times 1000$.

7. Acentric fragment resulting from non-division of the end gene of the chromosome followed by breakage. $\times 650$. 


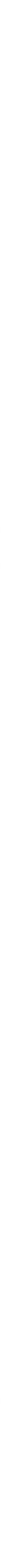


Anaphases and telophases can show incomplete separation of one or more pairs of chromosomes (fig. 7). The connection between two daughter chromosomes may continue after the new cell wall is laid down and may be present in the resting nucleus. Sometimes this is due to stickiness of the chromosome ends, which would eventually separate normally. Alternatively, however, these associations may be due to sister-reunion of the end gene to give a dicentric chromatid.
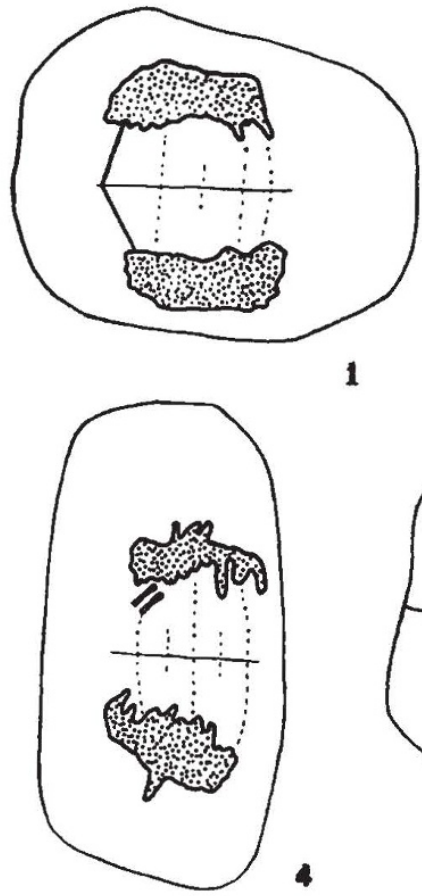

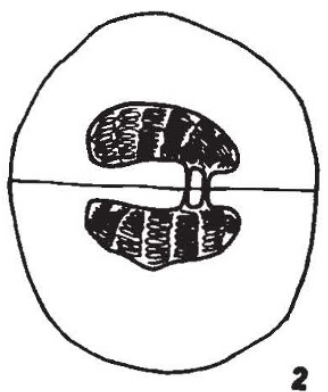

2

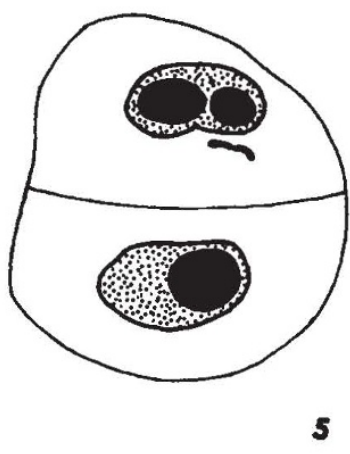

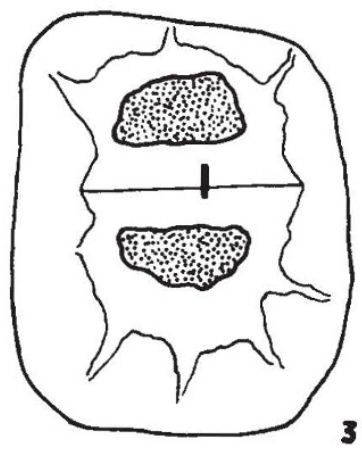

3

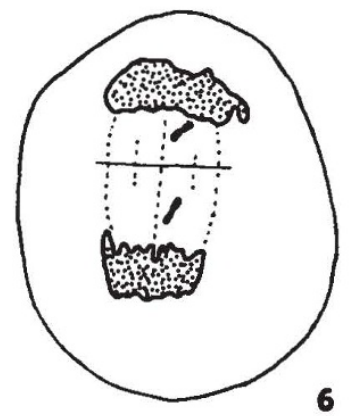

FIg. 7.-Errors of Division. Cells 1,2 and 3 show stages of non-division of the end gene and stickiness. Cells 4,5 and 6 show lagging chromosomes and non-disjunction. $\times 900$.

Movement of the centromeres at anaphase followed by breakage would produce acentric fragments and short fragment chromosomes. Fragment chromosomes have not been found in English varieties, though two examples were reported by Shimotomai (1933) in plants where $2 n=54+\mathrm{f}$. and $2 n=59+\mathrm{f}$., and also in C. lacustre $2 n=196+2 \mathrm{f}$. (Dowrick, 1952).*

\section{OTHER VARIATION}

Commercial growers are interested mainly in flower colour and shape, and they wish to change these characters only. Variation in chromosome number will not, however, be expected merely to change flower colour. Different sports of a family in fact proved to have characteristic leaf shapes (fig. 4) and also plant heights. Such changes and also chromosome variation can occur without affecting flower

\footnotetext{
* A small supernumerary euchromatic iso-chromosome has since been found in the
} large English variety Turbulent $(2 n 64+\mathrm{f}$. ) of unknown pedigree. 
colour. The grower eliminates these to keep his stock constant in size and appearance.

Similarly it has been shown by Bailey (I95I) that sports within a family differ in their susceptibility to disease. These differences may also be connected with variation in chromosome number.

\section{SUMMARY}

I. All ancestral species of the garden Chrysanthemum have a chromosome number of $2 n=6 x=54$. New varieties are produced from seed or bud sports.

2. The chromosome numbers of the English varieties lie between $47-63$. In both English and Japanese varieties there is a correlation between inflorescence size and chromosome number.

3. Variation in chromosome number within plants accounts for the origin of new varieties as vegetative sports. The amount of variation differs in different varieties and according to conditions.

4. Various types of chromosome loss and non-disjunction, responsible for variation, are found in both root and stem tips.

5. In some families of sports varying in chromosome number, there are differences in (i) flower colour, (ii) leaf shape and (iii) resistance to disease.

6. In their meiotic behaviour the hexaploid varieties normally have 27 bivalents and the unbalanced forms a minimum of irregularity.

Acknowledgments.-I wish to express my thanks to Dr C. D. Darlington for suggesting this and other problems connected with Chrysanthemum and for his continual advice; and also the Agricultural Research Council for the award of a scholarship during the tenure of which much of the work was undertaken.

\section{REFERENCES}

BAILEY, F. V. I95I. Observations on varietal resistance to Chrysanthemum rust. 7. Roy. Hort. Soc., 76, 322-328.

BRUMFIELD, R. T. 1943. Cell-lineage studies in root meristems by means of chromosome re-arrangements induced by X-rays. Amer. F. Bot., 30, 1 $01-1$ ro.

CURTIS, w. 1796. C. indicum. Indian chrysanthemum. Bot. Mag., No. 327.

DOWRICK, G. J. I 952 . The chromosomes of Chrysanthemum I. The species. Heredity $6,365-375$.

hemsley, w. B. I889. The history of the Chrysanthemum. Grdn. Chron., 6, 652-654.

O'MARA, J. c. 1948. Acetic acid methods for chromosome studies at prophase and metaphase in meristems. Stain. Tech., 23, 201-204.

POPHAM, R. A., and GHAN, A. P. 1950. Zonation in the vegetative stem-tip of Chrysanthemum morifolium. Amer. F. Bot., 37, 476-484.

SCOTT MONGRIEF, R. I936. A biochemical survey of some Mendelian factors for flower colour. 7. Genet., 32, 1 i 7-1 70 .

shimotomaI, N. 1933. Zur karyogenetik der gattung Chrysanthemum. F. Sci. Hiroshima Univ. Ser. B., 2, 1-1 oo.

stapf, o. 1933. C. makinoi. Curtis Bot. Mag., p. 9330. 